\title{
Synthesis and characterization of silicon nitride whiskers
}

\author{
MING - JONG WANG, HARUE WADA \\ Department of Materials Science and Engineering. The University of Michigan, Ann Arbor, \\ Michigan 48109, USA
}

Silicon nitride whiskers were synthesized by the carbothermal reduction of silica under nitrogen gas flow. The formation of silicon nitride whiskers occurs through a gas-phase reaction, $3 \mathrm{SiO}(\mathrm{g})+3 \mathrm{CO}(\mathrm{g})+2 \mathrm{~N}_{2}(\mathrm{~g})=\mathrm{Si}_{3} \mathrm{~N}_{4}(\beta)+3 \mathrm{CO}_{2}(\mathrm{~g})$, and the VS mechanism. The generation of $\mathrm{SiO}$ gas was enhanced by the application of a halide bath. Various nitrogen flow rates resulted in different whisker yields and morphologies. A suitable gas composition range of $\mathrm{N}_{2}, \mathrm{SiO}$ and $\mathrm{O}_{2}$ is necessary to make silicon nitride stable and grow in a whisker form. The oxygen partial pressure of the gas phase was measured by an oxygen sensor and the gas phase was analysed for $\mathrm{CO} / \mathrm{CO}_{2}$ by gas chromatography. Silicon nitride was first formed as a granule, typically a polycrystalline, and then grown as a single crystal whisker from the $\{100\}$ plane of the granule along the $\langle 210\rangle$ direction. The whiskers were identified as $\beta^{\prime}$-sialon with $\mathrm{Z}$ value ranging from 0.8 to 1.1 , determined by lattice parameter measurements.

\section{Introduction}

Ceramic whiskers, offering the advantages of high melting points, low densities and high moduli, have become important reinforcing materials in composites. The improving effects of ceramic whiskers on the mechanical properties of both ceramic-matrix composites [CMC] and metal-matrix composites [MMC] have been reported [1-4]. At present, silicon carbide whiskers are the most widely used and studied ceramic whiskers [1-6]. Since different matrices paired with different reinforcing materials would give specific advantages, other whiskers are expected to become the focus of studies as well. For instance, $\mathrm{Si}_{3} \mathrm{~N}_{4}(\mathrm{w})-$ Al composite has been reported [7] to be superior to $\mathrm{SiC}(\mathrm{w})-\mathrm{Al}$ composite with a higher tensile strength and better machinability. In fact, silicon nitride, with good high temperature strength and thermal shock resistance, is likely to be one of the candidates of reinforcing materials for high temperature composites.

Unlike $\mathrm{SiC}$ whisker, studies on the $\mathrm{Si}_{3} \mathrm{~N}_{4}$ whisker formation are very limited. Gribkov et al. [8] have formed $\alpha-\mathrm{Si}_{3} \mathrm{~N}_{4}$ whiskers from a mixture of $\mathrm{SiO}_{2}$ and $\mathrm{Si}$ in a $\left(\mathrm{N}_{2}+\mathrm{H}_{2}\right)$ atmosphere. The observation of droplets at whisker tips was evidence that whisker growth occurred by the VLS mechanism. The droplets were identified as $\mathrm{Al}-\mathrm{Si}$ or $\mathrm{Fe}-\mathrm{Si}$ alloy. Hayashi et al. [9] have grown $\mathrm{Si}_{3} \mathrm{~N}_{4}$ whiskers by the nitridation of the $\mathrm{SiO}_{2}-\mathrm{C}-\mathrm{Na}_{3} \mathrm{AlF}_{6}$ system. They reported that the whiskers contained about $85 \% \quad \beta^{\prime}$-sialon and $15 \%$ $\alpha-\mathrm{Si}_{3} \mathrm{~N}_{4}$ under optimum conditions. The $\beta^{\prime}$-sialon whiskers were 1 to $10 \mu \mathrm{m}$ in diameter and up to $10 \mathrm{~mm}$ in length. The $Z$ value of the $\beta^{\prime}$-sialon whiskers was estimated as 1.8 to 2.0 from the lattice parameters measurements by X-ray diffraction. They concluded that the whisker growth was by the VLS mechanism based on the droplets found at the tips of $\beta^{\prime}$-sialon whiskers. The droplets contained $\mathrm{Si}, \mathrm{Al}, \mathrm{Na} \mathrm{O}$ and $\mathrm{N}$.

One of the reasons which prevents ceramic whiskers from becoming a major reinforcing material of composites is cost. The main objective of this project is to develop a process which can synthesize ceramic whiskers in an economical way. This objective can be achieved by the following approaches: (1) using widely available silica and carbon as the low-cost materials, (2) developing a process that can synthesize either silicon nitride or silicon carbide whiskers with only minor changes in processing variables, and (3) applying an auxiliary bath to promote the reaction rate through an intimate contact between the two reactants.

The first approach is quite straightforward. Our earlier work [10], which involved a thermodynamic calculation to analyse the equilibria among the phases in the $\mathrm{Si}-\mathrm{C}-\mathrm{N}-\mathrm{O}$ system, provided insights regarding the second approach. These results were applied as a guideline to synthesize $\mathrm{Si}_{3} \mathrm{~N}_{4}$ and $\mathrm{SiC}$ whiskers selectively with the same process, only by changing the flowing gas [11]. The requirements of a suitable auxiliary bath for the third approach have been outlined in the same study [11]. The purpose of the present study is further to understand the formation mechanism of $\mathrm{Si}_{3} \mathrm{~N}_{4}$ whiskers and their characteristics.

\section{Experimental procedure}

\subsection{Whisker synthesis}

About $3 \mathrm{~g}$ of silica, carbon and halide $\left(3 \mathrm{NaF} \cdot \mathrm{AlF}_{3}\right.$ or $\mathrm{NaF}$ ) mixture with an atomic ratio of $\mathrm{Si}: \mathrm{C}: \mathrm{Na}=$ 1:3:1 was charged to a graphite tube inside a horizontal graphite reaction chamber, which was directly connected to a gas inlet at one end and an outlet at the 


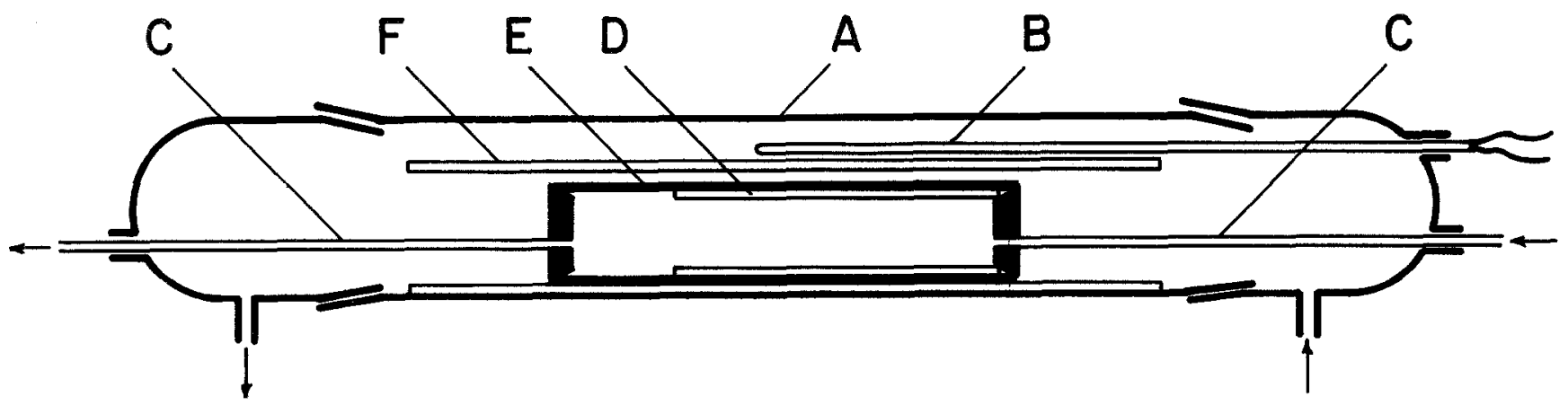

Figure I Schema of apparatus set-up. A, Mullite tube; B, thermocouple; C, gas inlet \& outlet; D, graphite tube; E, graphite reaction tube; $F$, alumina protection tube.

other. The graphite reaction chamber was placed in a mullite tube. Fig. 1 shows a schema of the apparatus set-up.

A high purity $\left(\mathrm{N}_{2}+3 \% \mathrm{H}_{2}\right)$ gas mixture was further purified through a $\mathrm{Mg}\left(\mathrm{ClO}_{4}\right)_{2}$ column, then introduced directly into the graphite reaction chamber. The gas flow rate was controlled by a Matheson 602 type flow meter, which had been calibrated by the bubble method. Four levels of flow rate were applied in this study: $25,50,75$ and $100 \mathrm{cc} \mathrm{min}^{-1}$.

All the reactions were carried out at $1623 \mathrm{~K}$ for $10 \mathrm{~h}$. The temperature was measured by a $\mathrm{Pt} / \mathrm{Pt}-$ $10 \% \mathrm{Rh}$ thermocouple. Upon the completion of reaction, the remaining carbon was oxidized in air at $973 \mathrm{~K}$. For the purpose of comparisons, one run was carried out with pure Si instead of silica as the starting material. The reaction conditions and the associated results are summarized in Table I. The wt $\%$ of the whiskers grown at the upper part (see the next Section) was determined after the remaining carbon was oxidized.

\subsection{Whisker characterization}

The reaction products were identified by $\mathrm{X}$-ray diffraction (XRD). Pure silicon was used as an internal standard to determine the lattice constants. The morphology and composition of whiskers were investigated by scanning electron microscope (SEM) and transmission electron microscope (TEM, Jeol 2000FX) microanalysis, respectively. Electron diffraction was applied to determine whisker growth direction.

\subsection{Gas analysis}

In selected runs, the oxygen partial pressure was measured continuously during the reaction by a $\mathrm{ZrO}_{2}(\mathrm{CaO})$ solid electrolyte. The exhaust gas in these runs was also collected at certain time intervals for
$\mathrm{CO} / \mathrm{CO}_{2}$ analysis by gas chromatography. The exhaust was led into a bubbler containing a saturated $\mathrm{PbCl}_{2}$ solution. The fluorine in the exhaust was collected as $\mathrm{PbClF}$ precipitate.

\subsection{Molten bath investigation}

An additional experiment was performed to examine the nature of the molten bath. Identical starting materials were heated to $1373 \mathrm{~K}$ in a graphite crucible in air. Samples of the melt were taken and quenched on a copper plate at certain time intervals. Phases and composition of the sample were analysed by XRD and $\mathrm{SEM} / \mathrm{EDS}$, respectively, after the remaining carbon in the sample was oxidized in the same manner as mentioned previously.

\section{Results and discussion}

\subsection{Whiskers}

Whiskers were formed at the original powder bed and around the wall of the graphite tube. Fig. 2 shows a typical product collected from the powder bed before carbon burning. White wool-like whiskers had formed at the upper part, while the lower part was a mixture of short whiskers and powders containing approximately $40 \mathrm{wt} \%$ of carbon. The letter B shown in Fig. 2 indicates the bottom area of the wool-like whiskers.

Fig. 3 is a TEM micrograph of the whiskers grown at the upper part. These whiskers are transparent under an electron microscope, and identified by XRD as $\beta^{\prime}$-sialon. The diameters of the whiskers are in a range from 0.5 to $1.2 \mu \mathrm{m}$, and the lengths are of the order of millimetres. The bottom part comprises short whiskers and powders, as shown in Fig. 4, and was identified by XRD as a mixture of $\beta^{\prime}$-sialon and $\mathrm{Si}_{2} \mathrm{~N}_{2} \mathrm{O}$.

Fig. 5 shows a typical result of TEM microanalysis

TABLE I Summary of reaction conditions

\begin{tabular}{|c|c|c|c|c|c|}
\hline \multirow[t]{2}{*}{ No. } & \multirow[t]{2}{*}{ Starting materials } & \multirow[t]{2}{*}{ Halide } & \multirow[t]{2}{*}{ Flow rate, $c \mathrm{cmin}-1$} & \multicolumn{2}{|l|}{ Phase identification } \\
\hline & & & & Upper whiskers (wt \%) & Lower mixture \\
\hline 1 & $\mathrm{SiO}_{2} / \mathrm{C}$ & $3 \mathrm{NaFAlF}_{6}$ & 25 & $\beta^{\prime}(24.3)$ & $\beta^{\prime}$, SNO \\
\hline 2 & $\mathrm{SiO}_{2} / \mathrm{C}$ & $3 \mathrm{NaFAlF}_{6}$ & 50 & $\beta^{\prime}(26.4)$ & $\beta^{\prime}, \mathrm{SNO}$ \\
\hline 3 & $\mathrm{SiO}_{2} / \mathrm{C}$ & $3 \mathrm{NaFAlF}_{6}$ & 75 & $\beta^{\prime}(28.4)$ & $\beta^{\prime}, \mathrm{SNO}$ \\
\hline 4 & $\mathrm{SiO}_{2} / \mathrm{C}$ & $3 \mathrm{NaFAlF}_{6}$ & 100 & $\beta^{\prime}(29.5)$ & $\beta^{\prime}, \mathrm{SNO}$ \\
\hline 5 & $\mathrm{SiO}_{2} / \mathrm{C}$ & $\mathrm{NaF}$ & 50 & $\alpha, \beta$ & SNO \\
\hline 6 & $\mathrm{Si} / \mathrm{C}$ & $3 \mathrm{NaFAlF}_{6}$ & 100 & - & $\alpha, \beta, \mathrm{Si}$ \\
\hline
\end{tabular}

$\beta^{\prime}: \beta^{\prime}$-sialon, $\mathrm{SNO}: \mathrm{Si}_{2} \mathrm{~N}_{2} \mathrm{O}, \alpha: \alpha-\mathrm{Si}_{3} \mathrm{~N}_{4}, \beta: \beta-\mathrm{Si}_{3} \mathrm{~N}_{4}$ 


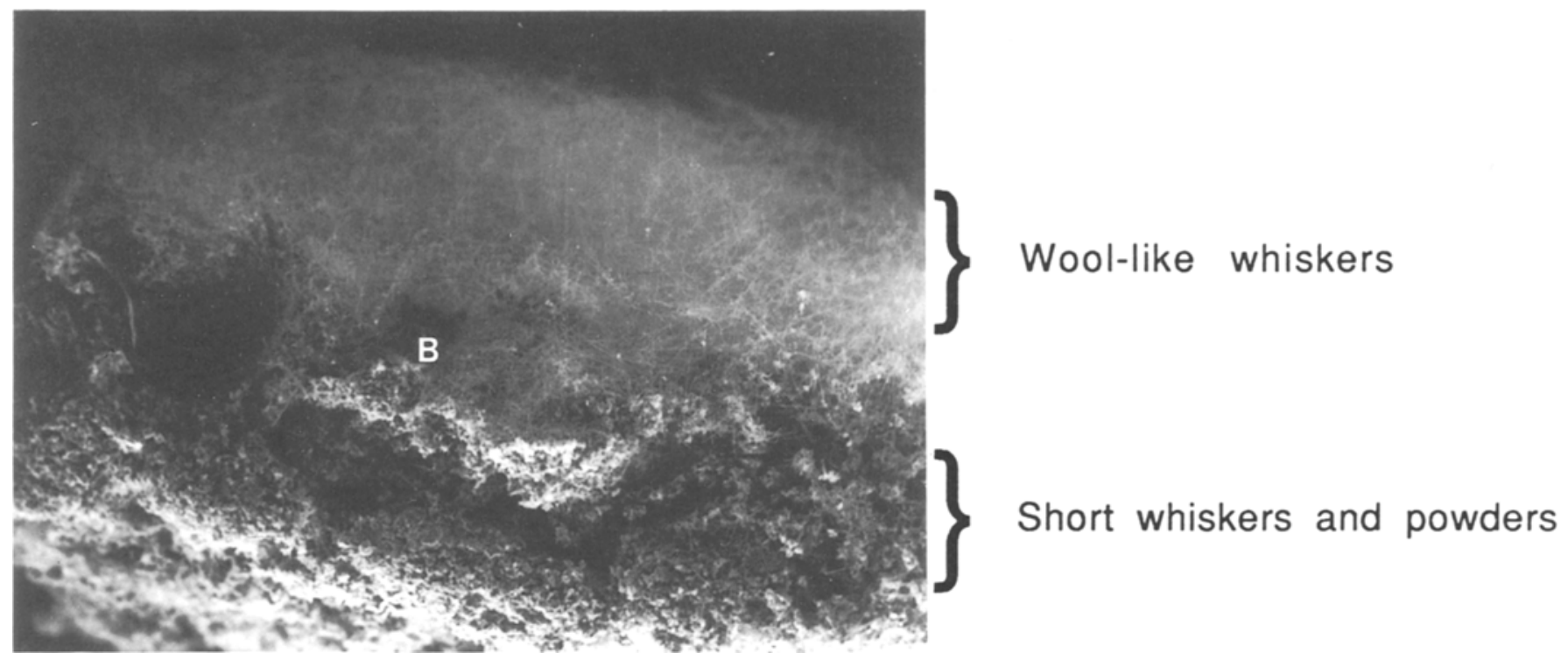

Figure 2 As-reacted product, before carbon burning, showing the wool-like whiskers at the upper part, the whiskers/powders mixture at the lower part and the bottom area of the wool-like whiskers indicated as the letter $B$.

of a $\beta^{\prime}$-sialon whisker. The $\mathrm{Si} K_{\alpha}$ and $\mathrm{Al} K_{\alpha}$ peaks are clearly seen from the X-ray energy spectrum, while no sodium peaks were detected. The $\mathrm{Si} / \mathrm{Al}$ ratio was determined by using the equation, $C_{\mathrm{Si}} / C_{\mathrm{Al}}=K_{\mathrm{Si}-\mathrm{Al}} I_{\mathrm{Si}} /$ $I_{\mathrm{Al}}$, where $C$ is element wt $\%, I$ is characteristic X-ray intensity and $K$ is Cliff-Lorimer factor. A $K_{\mathrm{Si}-\mathrm{Al}}=$ 1.002 was used in this study. Based on the measured $\mathrm{Si} / \mathrm{Al}$ atomic ratio, the $z$ value of $\beta^{\prime}$-sialon $\left(\mathrm{Si}_{6-z} \mathrm{Al}_{z}\right.$ $\mathrm{O}_{z} \mathrm{~N}_{8-z}$ ) was determined to be in the range from 0.8 to 1.1. The lattice parameters of $\beta^{\prime}$-sialon are closely related to the $z$ value, as demonstrated by Jack [12] and Hohnke and Tien [13]. Our results are in reasonable agreement with these studies.

Fig. 6 shows the whisker tip. Most of the whiskers have rectangular cross sections. The fact that no bulbs or droplets were ever observed at whisker tips suggests that the whisker growth was through the VS mechanism.

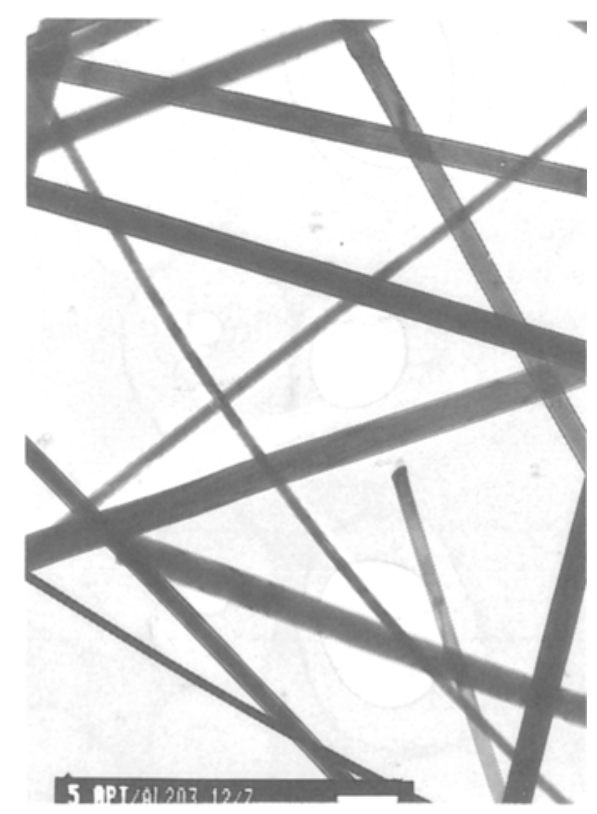

Figure 3 TEM micrograph of $\beta^{\prime}$-sialon whiskers from the upper part $($ bar $=1 \mu \mathrm{m})$.
Efforts were made to investigate the roots of the whiskers. Typically, a polycrystalline was found at the root from which the whisker grew along the $\langle 210\rangle$ direction, shown as Fig. 7. Fig. 8 reveals a relatively rare case in which a whisker stemmed from a single crystal. Both the whisker and the single crystal root have the same orientation, with $\langle 210\rangle$ as the growth direction. It can be concluded that $\mathrm{Si}_{3} \mathrm{~N}_{4}$ was first formed as a granule (either polycrystalline or single crystal), and then grew in a whisker form from the $\{100\}$ plane of the granule along the $\langle 210\rangle$ direction.

With $\left[3 \mathrm{NaF} \cdot \mathrm{AiF}_{3}\right]$ as the molten bath, $\beta^{\prime}$-sialon was the main product; however, when [NAF] substituted for $\left[3 \mathrm{NaF} \cdot \mathrm{AlF}_{3}\right], \alpha-\mathrm{Si}_{3} \mathrm{~N}_{4}$ became the dominant phase. The $\alpha-\mathrm{Si}_{3} \mathrm{~N}_{4}$ whisker is easily distinguished by the ribbon-like morphology, as shown in Fig. 9, with about $1 \mu \mathrm{m}$ in width and less than $0.1 \mu \mathrm{m}$ in thickness. The growth direction of the $\alpha-\mathrm{Si}_{3} \mathrm{~N}_{4}$ whisker is

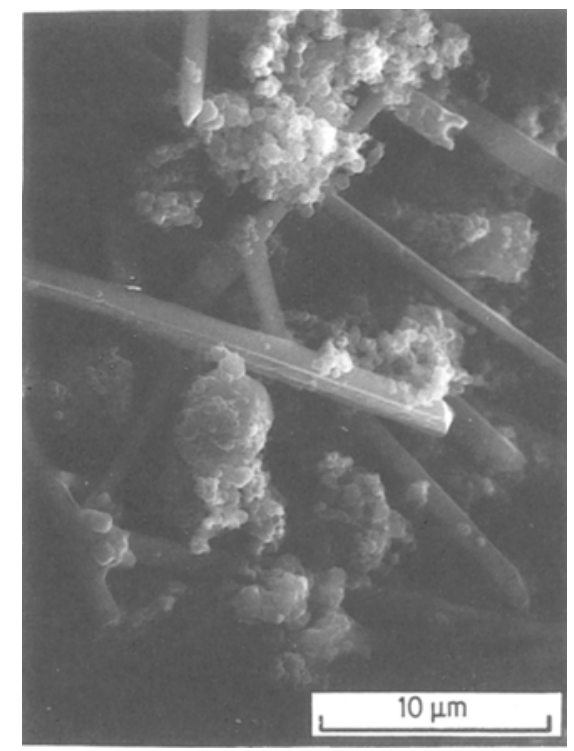

Figure 4 SEM micrograph of the lower part showing a mixture of whiskers and powders. 


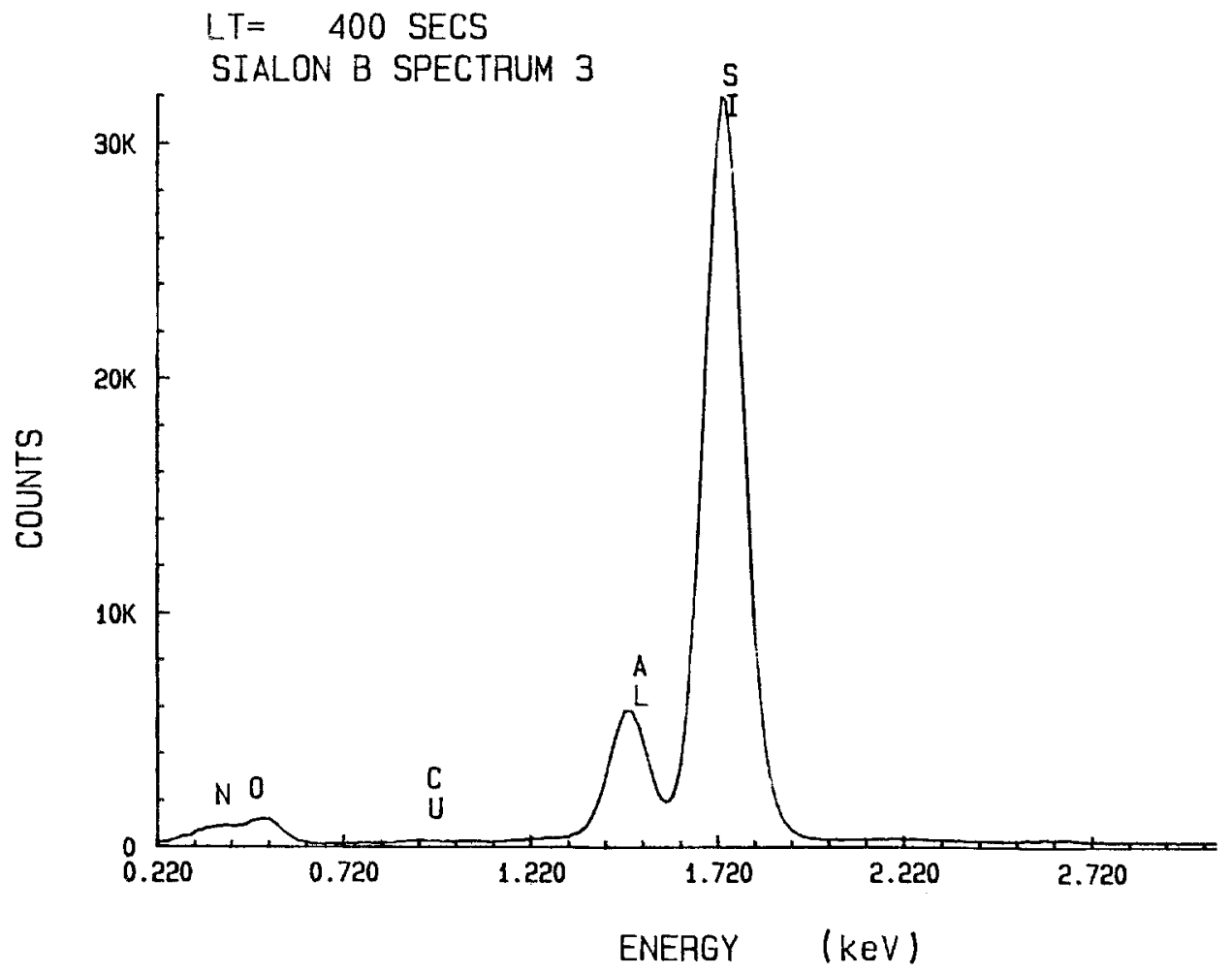

Figure 5 Typical X-ray energy spectrum of a $\beta^{\prime}$-sialon whisker.

$\langle 211\rangle$. The same morphology of $\alpha-\mathrm{Si}_{3} \mathrm{~N}_{4}$ whiskers was also reported by other studies $[8,14]$.

\subsection{Gas phase}

The equilibrium partial pressure of oxygen was measured by a $\mathrm{ZrO}_{2}$ sensor. The galvanic cell with a $\mathrm{ZrO}_{2}-(15 \mathrm{~mol} \% \mathrm{CaO})$ solid electrolyte can be denoted as

$\mathrm{Mo} / \mathrm{O}_{2}\left(\mathrm{Mo}-\mathrm{MoO}_{2}\right) / \mathrm{ZrO}_{2}(\mathrm{CaO}) / \mathrm{O}_{2}$ (in reaction) $/ \mathrm{Mo}$

The detailed structure of the $\mathrm{ZrO}_{2}$ electrolyte and a method to determine the oxygen partial pressure can be found in [15] and [11].

Typically, the measured values of $p_{\mathrm{O}_{2}}$ were about $10^{-22} \mathrm{~atm}$ throughout the reaction period. Referring

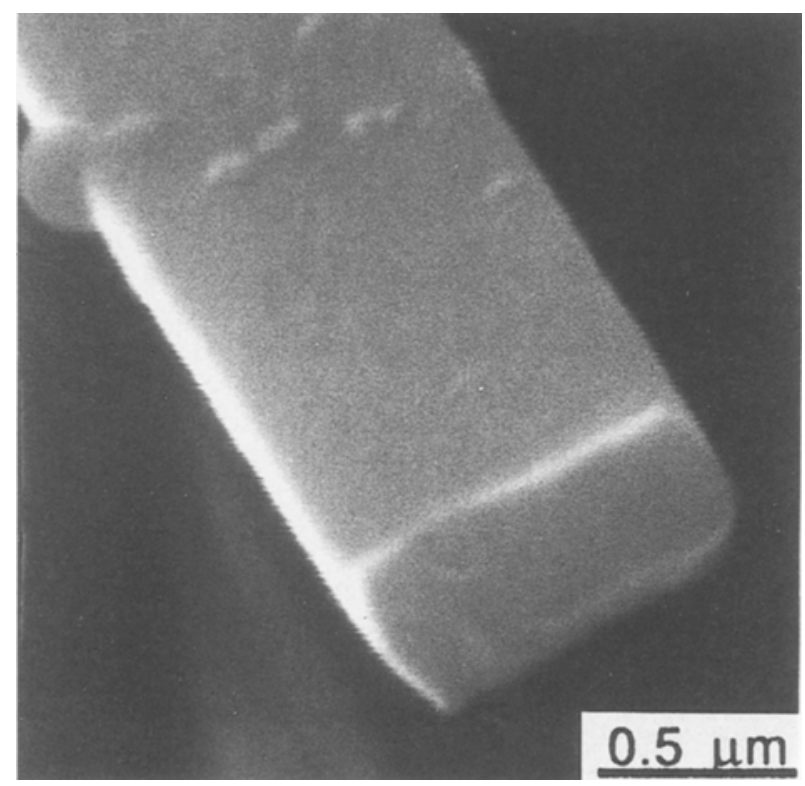

Figure 6 SEM micrograph of $\beta^{\prime}$-sialon whisker showing a rectangular cross section. to the stability diagram (Fig. 8 in ref $[10]$ ), a $p_{\mathrm{O}_{2}}=$ $10^{-22} \mathrm{~atm}$ is within the stable region of $\mathrm{Si}_{3} \mathrm{~N}_{4}$ at $a_{\mathrm{C}}=1, p_{\mathrm{N}_{2}}=1 \mathrm{~atm}$ and $T=1623 \mathrm{~K}$.

The equilibrium $p_{\mathrm{CO}}$ was calculated from the measured $p_{\mathrm{O}_{2}}$ for $a_{\mathrm{C}}=1$ based on the following reaction,

$$
\mathrm{C}(\mathrm{s})+1 / 2 \mathrm{O}_{2}(\mathrm{~g})=\mathrm{CO}(\mathrm{g})
$$

The measured $p_{\mathrm{CO}}$ and $p_{\mathrm{CO}_{2}}$ and the calculated $p_{\mathrm{CO}}$ are summarized in Table II. Taking into consideration the fact that the exhaust gas was collected at a much lower temperature, the agreement between the two values is reasonable. It indicates that $p_{\mathrm{O}_{2}}$ and $p_{\mathrm{CO}}$ were very close to their equilibrium values during the reaction. The $\mathrm{CO}_{2}$ content in the exhaust was always below the analytical limit of $0.025 \mathrm{vol} \%$. The equilibrium $p_{\mathrm{CO}_{2}}$ calculated at $1623 \mathrm{~K}$ and $a_{\mathrm{C}}=1$ for the following reaction is also lower than the analytical limit.

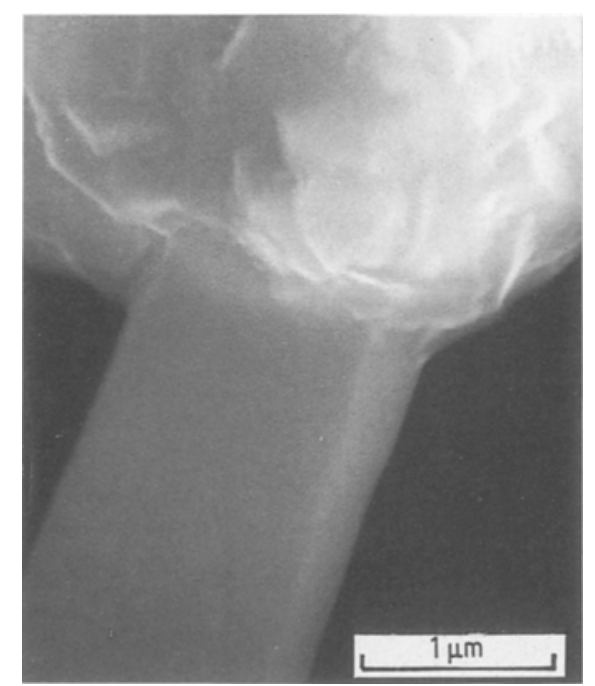

Figure 7 SEM micrograph showing a polycrystalline granule at the root of a $\beta^{\prime}$-sialon whisker. 

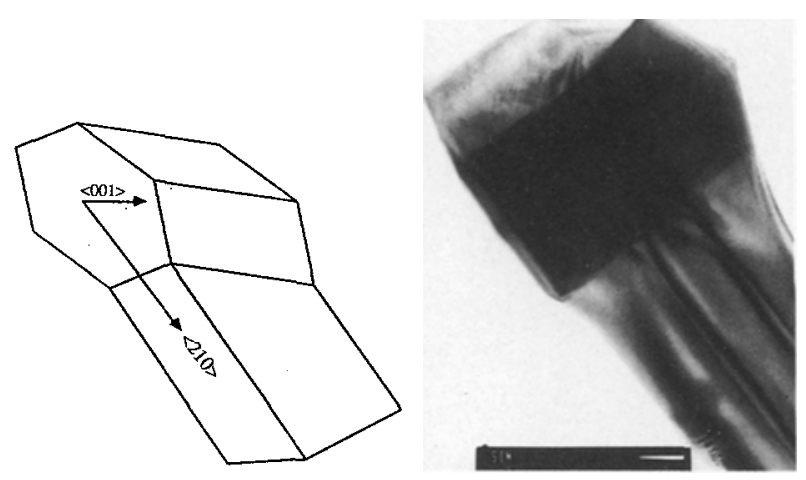

Figure 8 TEM micrograph of a $\beta^{\prime}$-sialon whisker originated from a single crystal and an illustration of the whisker growth direction (bar $=100 \mathrm{~nm})$.

$$
\mathrm{CO}_{2}(\mathrm{~g})+\mathrm{C}(\mathrm{S})=2 \mathrm{CO}(\mathrm{g})
$$

Therefore, it can be concluded that $\mathrm{CO} / \mathrm{CO}_{2}$ were also in equilibrium. Since the value of the equilibrium constant of the $\mathrm{CO} / \mathrm{CO}_{2}$ reaction is high $\left(K_{2}=3.68 \times\right.$ $10^{3}$ at $1623 \mathrm{~K}$ ), the effect of $p_{\mathrm{CO}_{2}}$ on whisker formation would be minimal when $a_{\mathrm{C}}=1$.

\subsection{Molten bath}

Fig. 10 shows a SEM micograph of the quenched molten $\left[3 \mathrm{NaF} \cdot \mathrm{AlF}_{3}\right]$ bath, with a Si X-ray map. The spherical morphology suggests that the molten bath had high surface tension and might have formed as molten droplets during the reaction. The uniform distribution of $\mathrm{Si}$ indicates that silica has dissolved into the molten bath. Although the phase diagram of the $\mathrm{SiO}_{2}-\mathrm{NaF}-\mathrm{AlF}_{3}$ system is not available, it is well established that $\left[\mathrm{Na}_{3} \mathrm{AlF}_{6}\right]$ forms low melting-point liquids with several other metallic oxides [16]. Saito et al. [17] have suggested that the addition of $\mathrm{NaF}$, $\mathrm{CaF}_{2}$ and $\mathrm{Na}_{3} \mathrm{AlF}_{6}$ to $\mathrm{SiO}_{2}$ forms fluorosilicate melts at $1623 \mathrm{~K}$. It is likely that the molten halide bath became $\mathrm{Na}-\mathrm{Al}$ fluorosilicate as silica dissolved.

Low viscosity is one of the important factors in selecting a suitable auxiliary bath, since it is anticipated to affect the contact between silica and carbon as well as the gas evolution. The addition of fluoride is well known for reducing the viscosity of oxide melts $[18,19]$. To evaluate the effect of the halide bath on the reaction between silica and carbon, carbon consumptions by the carbothermal reduction of silica were compared for the cases with and without the halide bath. Only $8 \%$ of the charged carbon was consumed when the bath was not applied, whereas the consumed carbon was about $35 \%$ in the presence of the halide bath. The carbothermal reduction of silica is expressed as:

$$
\mathrm{SiO}_{2}(\mathrm{~s} / 1)+\mathrm{C}(\mathrm{s})=\mathrm{SiO}(\mathrm{g})+\mathrm{CO}(\mathrm{g})
$$

TABLE II $\mathrm{CO} / \mathrm{CO}_{2}$ Composition of the exhaust gas

\begin{tabular}{lllll}
\hline $\begin{array}{l}\text { Sample } \\
\text { no }\end{array}$ & $\begin{array}{l}\text { Collecting time*, } \\
\text { min }\end{array}$ & $\begin{array}{l}\mathrm{CO} \\
\text { vol \% }\end{array}$ & $\begin{array}{l}\mathrm{CO}_{2} \\
\text { vol \% }\end{array}$ & $\begin{array}{l}\text { Calculated } \\
p_{\mathrm{CO}}, \text { atm }\end{array}$ \\
\hline 1 & 10 & 2.00 & $<0.025$ & 0.029 \\
2 & 180 & 2.83 & $<0.025$ & 0.021 \\
3 & 480 & 1.80 & $<0.025$ & 0.037 \\
\hline
\end{tabular}

*Time after the reaction temperature reached $1623 \mathrm{~K}$.

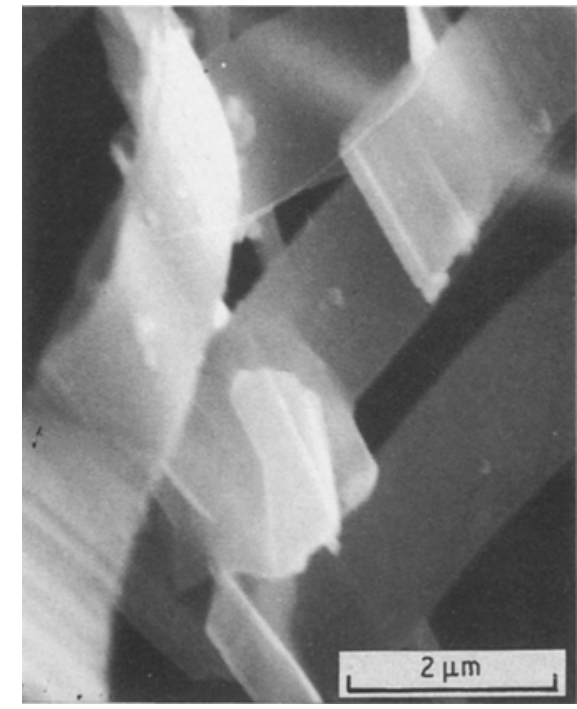

Figure 9 SEM micrograph of $\alpha-\mathrm{Si}_{3} \mathrm{~N}_{4}$ whiskers with $\mathrm{NaF}$ as molten bath.

The intimate contact between silica and carbon through the liquid phase resulted in the higher consumption rate of carbon. The evolution of $\mathrm{SiO}$ and $\mathrm{CO}$ gases from the spherical and low-viscosity molten droplets might have been assisted by the evolution of other gases, such as fluorine and fluorides. The craterlike openings on the surface of the quenched sample as seen in Fig. 10 may be evidence of gas evolution. The findings of $[\mathrm{NaF}]$ and $\left[3 \mathrm{NaF} \cdot \mathrm{AlF}_{3}\right]$ by $\mathrm{XRD}$ in the vaporized/condensed deposit at low-temperature area of the gas outlet confirmed the evolution of fluoride gases.

The $\mathrm{pH}$ value of the saturated $\mathrm{PbCl}_{2}$ solution was changed as the exhaust was led into the bubbler, through the following reaction,

$$
\mathrm{PbCl}_{2}+\mathrm{F}^{-}=\operatorname{PbClF}(\mathrm{s})+\mathrm{Cl}^{-}
$$

The $\mathrm{pH}$ value started to drop abruptly as the temperature approached the melting point of $\left[3 \mathrm{NaF} \cdot \mathrm{AlF}_{3}\right]$, $1282 \mathrm{~K}$, and levelled off within 30 minutes. This fact implies that fluorine and fluorides started to evaporate at a very high rate during the early stages of melting, then the evaporation reduced until a steady rate was reached. Both the dissolution of silica into the melt and the initial evaporation of fluorine and fluorides from the melt could increase the viscosity of the melt and reduce the subsequent evaporation rate of fluorine and fluorides.

The quenched molten bath was identified as a mixture of $[\mathrm{NaF}]$ and $\left[3 \mathrm{NaF} \cdot \mathrm{AlF}_{3}\right]$ by XRD. The relative amount of $[\mathrm{NaF}]$ increased with increasing holding time. Thus the composition of the molten bath has shifted from $\left[\mathrm{Na}_{3} \mathrm{AlF}_{6}\right]$ toward the $[\mathrm{NaF}]$ rich end, referring to the $\mathrm{NaF}-\mathrm{AlF}_{3}$ phase diagram [20], which is in agreement with the fact that $\left[\mathrm{AlF}_{3}\right]$ has a higher vapour pressure than $[\mathrm{NaF}]$.

\subsection{Reaction mechanism \\ 3.4.1. Silicon nitride}

As discussed previously, the whisker formation is likely through the VS mechanism. There are three possible reaction routes that could be responsible for the $\mathrm{Si}_{3} \mathrm{~N}_{4}$ 

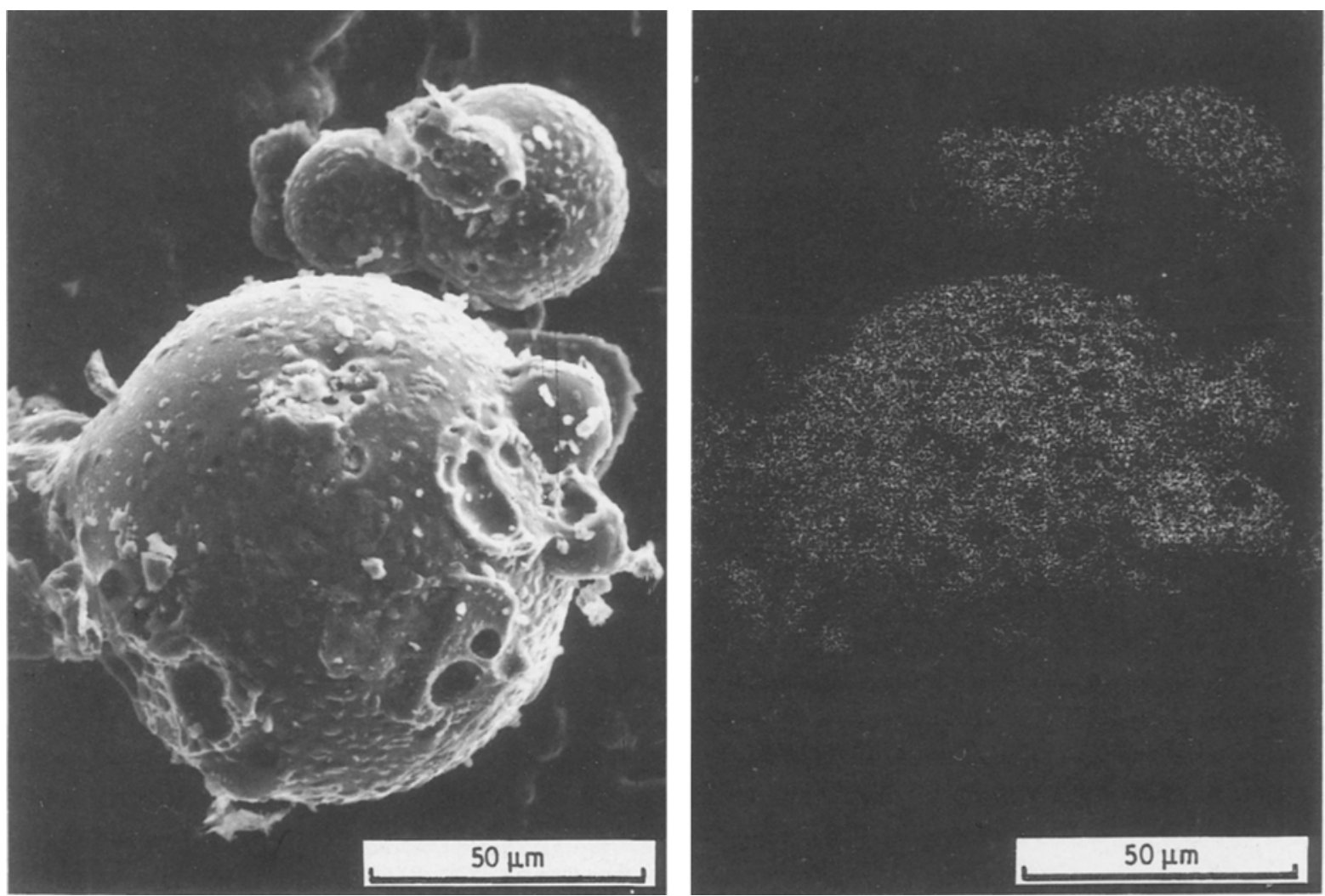

Figure 10 SEM micrograph of quenched halide bath and the X-ray map of Si.

whisker formation:

$$
\begin{gathered}
3 \mathrm{SiO}(\mathrm{g})+3 \mathrm{CO}(\mathrm{g})+2 \mathrm{~N}_{2}(\mathrm{~g}) \\
=\mathrm{Si}_{3} \mathrm{~N}_{4}(\beta)+3 \mathrm{CO}_{2}(\mathrm{~g})
\end{gathered}
$$

$\Delta G^{\circ}=-1437.972+0.942 T, \mathrm{~kJ} \mathrm{~mol}^{-1}$ of $\mathrm{Si}_{3} \mathrm{~N}_{4}$

$3 \mathrm{SiO}(\mathrm{g})+3 \mathrm{C}(\mathrm{s})+2 \mathrm{~N}_{2}(\mathrm{~g})=\mathrm{Si}_{3} \mathrm{~N}_{4}(\beta)+3 \mathrm{CO}(\mathrm{g})$

$\Delta G_{6}^{\circ}=-952.356+0.438 T, \quad \mathrm{~kJ} \mathrm{~mol}^{-1}$ of $\mathrm{Si}_{3} \mathbf{N}_{4}$

$$
\begin{gathered}
3 \mathrm{SiF}_{4}(\mathrm{~g})+2 \mathrm{~N}_{2}(\mathrm{~g})=\mathrm{Si}_{3} \mathrm{~N}_{4}(\beta)+6 \mathrm{~F}_{2}(\mathrm{~g}) \\
\Delta G_{7}^{\circ}=3920.19+0.018 T, \quad \mathrm{~kJ} \mathrm{~mol}^{-1} \text { of } \mathrm{Si}_{3} \mathrm{~N}_{4}
\end{gathered}
$$

All the standard free energies of formation used in this study were obtained from JANAF Tables [21], except that of $\mathrm{Si}_{3} \mathrm{~N}_{4}(\beta)$ and $\mathrm{Si}_{2} \mathrm{~N}_{2} \mathrm{O}(\mathrm{s})$, which were from the same source as described in [10]. The contribution from Equation (7) is considered to be insignificant for the following reasons: (1) the free energy change of Equation (7) is $3949 \mathrm{~kJ}$ at $1623 \mathrm{~K}$ which is much higher than those of Equation (5) and (6), $91 \mathrm{~kJ}$ and $-241 \mathrm{~kJ}$, respectively, and (2) the fluorine recovery as the $\mathrm{PbClF}$ precipitate was always about $40 \%$ despite the fact that the Si yield changed as reaction conditions were changed. However, the evolution of $\mathrm{SiF}_{4}(\mathrm{~g})$ from the melt may enhance the evolution of $\mathrm{SiO}(\mathrm{g})$. The necessary presence of solid carbon at the reaction site, i.e., the whisker tip, rules out the possibility of the gas-solid reaction of Equation (6) as the major reaction, especially when the whiskers were as long as millimetres; furthermore, $\mathrm{Si}_{3} \mathrm{~N}_{4}$ whiskers have been found on an alumina substrate where solid carbon is absent. Therefore, Equation (5) is the most probable reaction for the $\mathrm{Si}_{3} \mathrm{~N}_{4}$ whisker formation.

The importance of $\mathrm{SiO}$ gas for $\mathrm{Si}_{3} \mathrm{~N}_{4}$ whisker formation was clearly demonstrated by replacing $\mathrm{SiO}_{2}$ with $\mathrm{Si}$ as the starting material (No. 6 in Table I): no whiskers were formed and the carbon consumption was only one-fourth of that in the $\mathrm{SiO}_{2}$ cases of the same reaction conditions. The major morphology of the product was the hexagonal particulate, as shown in Fig. 11. X-ray diffraction indicated that the product was a mixture of $\alpha-, \beta-\mathrm{Si}_{3} \mathrm{~N}_{4}$ and about $40 \mathrm{wt} \%$ of $\mathrm{Si}$. The remaining Si was identified as the unreacted starting $\mathrm{Si}$ from the partially changed morphology.

For the crystal grown from the vapour phase, it is generally believed that the growth form is closely related to the supersaturation ratio [22], which is a combination of the concentrations of the reactant gases. In general, a lower supersaturation ratio favours the formation of whiskers, whereas a higher supersaturation would result in powders. Since the gasphase reaction of Equation (5) is the route for $\mathrm{Si}_{3} \mathrm{~N}_{4}$ formation, the growth form of $\mathrm{Si}_{3} \mathrm{~N}_{4}$ is closely related to the partial pressures of $\mathrm{N}_{2}, \mathrm{SiO}$ and $\mathrm{CO} / \mathrm{CO}_{2}$.

The relative amount of the wool-like whiskers (the upper part) increases with increasing the nitrogen flow rate, as summarized in Table I. One of the effects of an increasing flow rate is a larger supply of nitrogen gas to the reaction zone. However, a higher flow rate could also change the partial pressures of $\mathrm{SiO}(\mathrm{g})$ and $\mathrm{CO}(\mathrm{g})$ at the reaction zone and result in a supersaturation ratio suitable for the formation of $\mathrm{Si}_{3} \mathrm{~N}_{4}$ in whisker form.

Fig. 12 is a close-up of the bottom area of the wool-like whiskers (area B in Fig. 2). It is clear that 


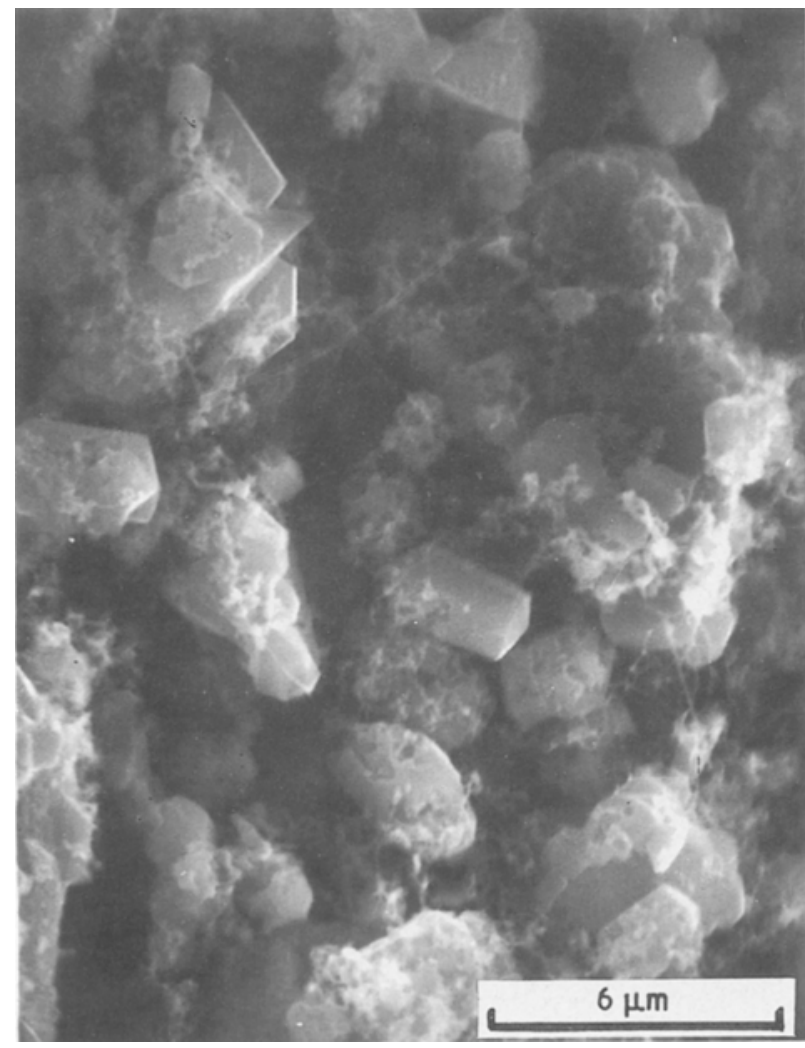

Figure 11 SEM micrograph of the product with $\mathrm{Si}$ as starting material.

some of the whiskers in this area have "knuckles" which formed during their growth. SEM/EDX showed that both whiskers and knuckles have the same $\beta^{\prime}$-sialon composition. Most of the knuckles were identified as polycrystalline by electron diffraction, while the whisker portions between knuckles were single crystals. It seems that the anisotropic whisker growth and the isotropic polycrystalline growth have occurred alternately in these particular whiskers. From the fact that these whiskers were only found at the bottom area of the wool-like whiskers, it suggests that the formation of these whiskers is location-related. Even though it is not yet clear how the nitrogen gas reaches the bottom area (e.g. by physically flowing or dissolving into the melt), the supply of nitrogen to this area would not be as easy as to the upper area. Deeper in the powder bed (the lower part), the nitrogen supply could even be less sufficient. As a result, the gas composition is expected to fluctuate during the formation of whiskers in the bottom area. The changing gas composition around the growing whisker in the bottom area probably is responsible for the change of growth form, i.e. from whisker to knuckle and vice versa. The even less sufficient supply of nitrogen in the lower part might result in a supersaturation ratio which made $\mathrm{Si}_{3} \mathrm{~N}_{4}$ in powder form.

The formation of $\beta^{\prime}$-sialon can be expressed as the following reaction,

$$
\begin{gathered}
(6-z) \mathrm{SiO}(\mathrm{g})+(4-z / 2) \mathrm{N}_{2}(\mathrm{~g}) \\
+(6-2 z) \mathrm{CO}(\mathrm{g})+z \mathrm{Al}(\mathrm{g}) \\
=\mathrm{Si}_{(6-z)} \mathrm{Al}_{z} \mathrm{O}_{z} \mathrm{~N}_{(8-z)}+(6-2 z) \mathrm{CO}_{2}(\mathrm{~g})
\end{gathered}
$$

Because aluminium and oxygen substitute for silicon

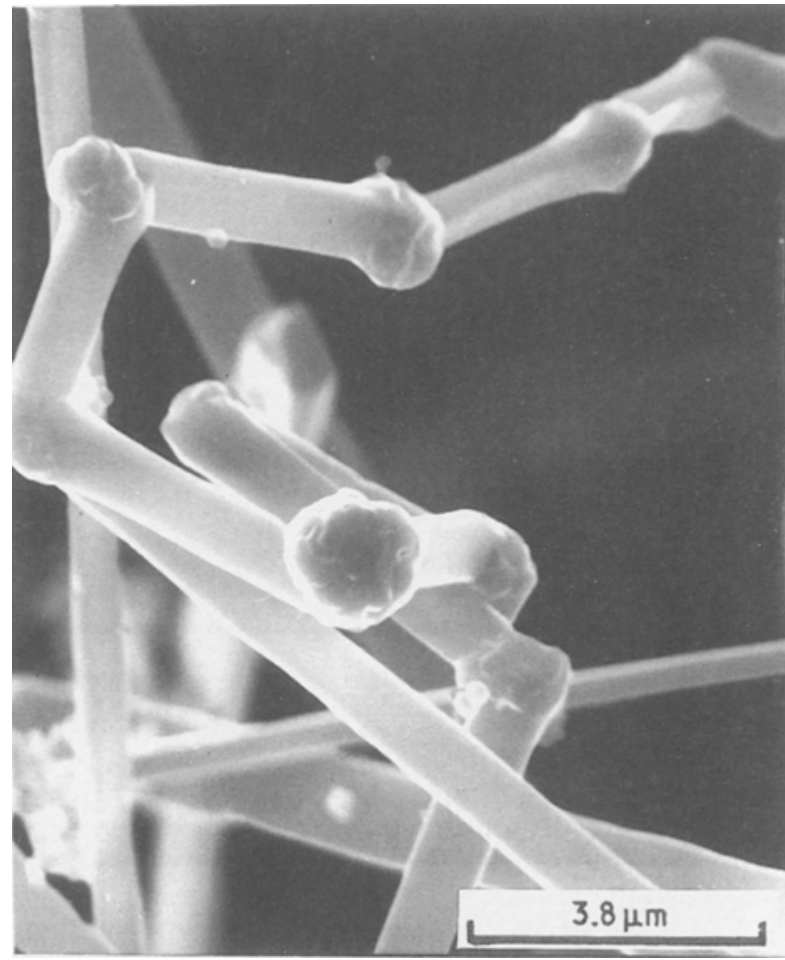

Figure 12 SEM micrograph showing whiskers with knuckles from the bottom area of the wool-like whiskers.

and nitrogen, respectively, in forming $\beta^{\prime}$-sialon, the oxygen partial pressure in the gas phase is expected to become lower. The presence of aluminium seems to stabilize the $\beta$-type structure by (1) forming $\beta^{\prime}$-sialon that is $\beta$-type, and (2) dissolving oxygen into $\beta^{\prime}$-sialon and hence reduces $p_{\mathrm{O}_{2}}$ in the gas phase. The $\beta$-type is known to be more stable than the $\alpha$-type at lower $p_{\mathrm{O}_{2}}$. In the absence of aluminium, both $\alpha$ - and $\beta$-type would grow competitively, depending on the temperature and $p_{\mathrm{O}}$. This may explain the observation of $\alpha-\mathrm{Si}_{3} \mathrm{~N}_{4}$ whiskers when $\mathrm{NaF}$ was used as the halide bath (No. 5 in Table I).

\subsubsection{Silicon oxynitride}

$\mathrm{Si}_{2} \mathrm{~N}_{2} \mathrm{O}$ was found at the lower part along with $\mathrm{Si}_{3} \mathrm{~N}_{4}$, even though the oxygen partial pressure was low enough to suppress its formation. A thermodynamic calculation was carried out to futher analyse the effects of gas composition, including $\mathrm{SiO}(\mathrm{g})$, on the stability of phases in the $\mathrm{Si}-\mathrm{C}-\mathrm{N}-\mathrm{O}$ system.

In the Si-C-N-O system, the formations of solid phases from the major gas phase components can be expressed as follows:

$$
\begin{gathered}
3 \mathrm{SiO}(\mathrm{g})+3 \mathrm{C}(\mathrm{s})+2 \mathrm{~N}_{2}(\mathrm{~g})=\mathrm{Si}_{3} \mathrm{~N}_{4}(\beta)+3 \mathrm{CO}(\mathrm{g}) \\
\log K_{9}=\log a_{\mathrm{Si}_{3} \mathrm{~N}_{4}}+3 \log p_{\mathrm{CO}} \\
-3 \log p_{\mathrm{SiO}}-3 \log a_{\mathrm{C}}-2 \log p_{\mathrm{N}_{2}} \\
=49747 / T-22.8 \\
2 \mathrm{SiO}(\mathrm{g})+\mathrm{C}(\mathrm{s})+\mathrm{N}_{2}(\mathrm{~g})=\mathrm{Si}_{2} \mathrm{~N}_{2} \mathrm{O}(\mathrm{s})+\mathrm{CO}(\mathrm{g})
\end{gathered}
$$

$$
\begin{gathered}
\log K_{10}=\log a_{\mathrm{S}_{2} \mathrm{~N}_{2} \mathrm{O}}+\log p_{\mathrm{CO}} \\
-2 \log p_{\mathrm{SiO}_{\mathrm{O}}}-\log a_{\mathrm{C}}-\log p_{\mathrm{N}_{2}} \\
=29211 / T-10.81
\end{gathered}
$$




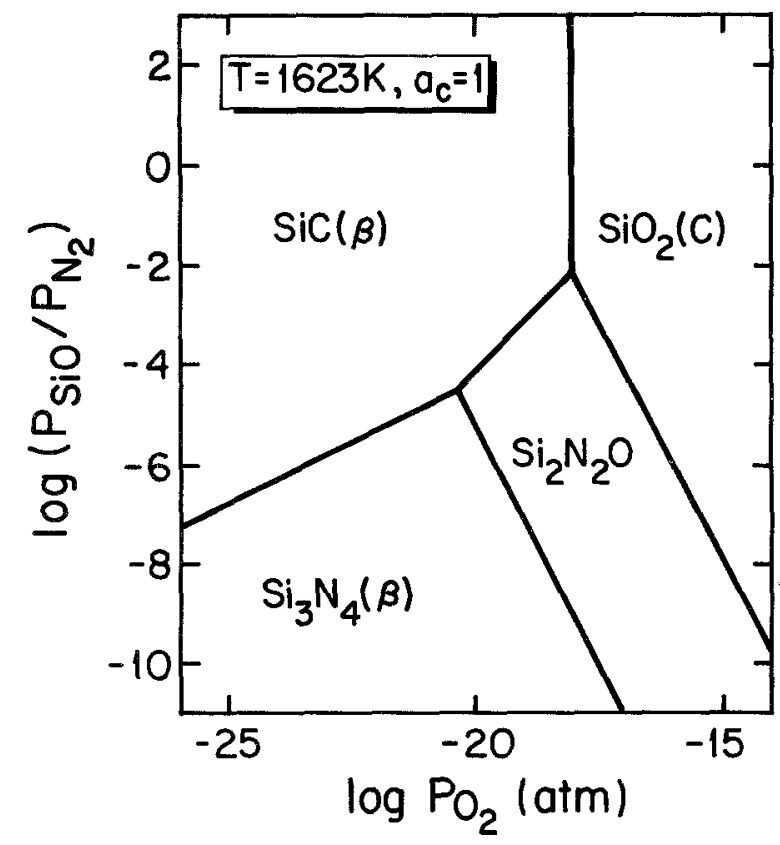

Figure 13 Phase stability diagram as a function of $p_{\mathrm{O}_{2}}$ and $p_{\mathrm{SiO}} / p_{\mathrm{N}_{2}}$ at $T=1623 \mathrm{~K}$ and $a_{\mathrm{C}}=1$.

$$
\mathrm{SiO}(\mathrm{g})+2 \mathrm{C}(\mathrm{s})=\mathrm{SiC}(\beta)+\mathrm{CO}(\mathrm{g})
$$

$\log K_{11}=\log a_{\mathrm{SiC}}+\log p_{\mathrm{CO}}-\log p_{\mathrm{SiO}}-2 \log a_{\mathrm{C}}$

$$
=4277 / T-0.16
$$

$$
\mathrm{SiO}(\mathrm{g})+\mathrm{CO}(\mathrm{g})=\mathrm{SiO}_{2}(\mathrm{c})+\mathrm{C}(\mathrm{s})
$$

$$
\begin{aligned}
\log K_{12} & =\log a_{\mathrm{SiO}_{2}}+\log a_{\mathrm{C}}-\log p_{\mathrm{SiO}}-\log p_{\mathrm{CO}} \\
& =35261 / T-17.50
\end{aligned}
$$

The partial pressures of $\mathrm{SiO}(\mathrm{g}), \mathrm{N}_{2}(\mathrm{~g})$ and $\mathrm{CO}(\mathrm{g})$ for each equilibrium were determined by solving the related two equations; for instance, Equations 9-1 and 10-1 were solved simultaneously at given conditions for the $\mathrm{Si}_{3} \mathrm{~N}_{4} / \mathrm{Si}_{2} \mathrm{~N}_{2} \mathrm{O}$ equilibrium. Since solid $\mathrm{Si}_{3} \mathrm{~N}_{4}$ and $\mathrm{Si}_{2} \mathrm{~N}_{2} \mathrm{O}$ were in equilibrium, $a_{\mathrm{Si}_{3} \mathrm{~N}_{4}}=a_{\mathrm{Si}_{2} \mathrm{~N}_{2} \mathrm{O}}=1$. If $a_{\mathrm{C}}=1$ (referred to graphite) and $p_{\mathrm{CO}}=10^{-2} \mathrm{~atm}$, then $p_{\mathrm{SiO}}$ and $p_{\mathrm{N}_{2}}$ were calculated as $2.57 \times 10^{-5} \mathrm{~atm}$ and $1 \mathrm{~atm}$ respectively, at $T=1623 \mathrm{~K}$. The same principle was applied to other equilibria. For the purpose of comparisons with the established stability diagrams [10], the $p_{\mathrm{CO}}$ values were converted to $p_{\mathrm{O}_{2}}$ based on the equilibrium of Equation 1. A stability diagram which shows the relationship between the gas phase composition and the stable solid phases was constructed as a function of $p_{\mathrm{O}_{2}}$ and $\left(p_{\mathrm{SiO}} / p_{\mathrm{N}_{2}}\right)$ ratio, as shown in Fig. 13. The corresponding $p_{\mathrm{N}_{2}}$ and $p_{\mathrm{O}_{2}}$ at each invariant point are consistent with the values determined previously [10].

Each boundary in Fig. 13 represents the equilibrium $p_{\mathrm{O}_{2}}$ and $\left(p_{\mathrm{SiO}} / p_{\mathrm{N}_{2}}\right)$ of the corresponding two solid phases at $1623 \mathrm{~K}$. Considering the equilibrium between $\mathrm{Si}_{3} \mathrm{~N}_{4}(\beta)$ and $\mathrm{Si}_{2} \mathrm{~N}_{2} \mathrm{O}$, there is a specific $\left(p_{\mathrm{Sio}} / p_{\mathrm{N}_{2}}\right)$ ratio at a given $p_{\mathrm{O}_{2}}$. If the $\left(p_{\mathrm{SiO}} / p_{\mathrm{N}_{2}}\right)$ ratio of a gas phase is higher than the specific value for the given $p_{\mathrm{O}_{2}}, \mathrm{Si}_{2} \mathrm{~N}_{2} \mathrm{O}$ is the stable phase, whereas $\mathrm{Si}_{3} \mathrm{~N}_{4}(\beta)$ becomes stable if the $\left(p_{\mathrm{Sio}} / p_{\mathrm{N}_{2}}\right)$ ratio is lower than the specific value. The ( $p_{\mathrm{SiO}} / p_{\mathrm{N}_{2}}$ ) ratio at the lower part might be considerably higher than at the upper part, because there might not be a sufficient supply of nitrogen gas to the lower part of the melt and the generated $\mathrm{SiO}$ gas might not leave freely. It could be concluded that the localized high $\left(p_{\mathrm{SiO}} / p_{\mathrm{N}_{2}}\right)$ ratio was responsible for the formation of $\mathrm{Si}_{2} \mathrm{~N}_{2} \mathrm{O}$ at the lower part, even under the very low oxygen partial pressure in the gas phase.

\section{Summary}

(1) The formation of $\mathrm{Si}_{3} \mathrm{~N}_{4}$ and $\beta^{\prime}$-sialon whiskers occurs through a gas-phase reaction involving $\mathrm{SiO}(\mathrm{g})$, and VS mechanism.

(2) $\beta^{\prime}$-sialon was first formed as a granule, typically a polycrystalline, and then grown as a single crystal whisker from the $\{100\}$ plane of the granule along the $\langle 210\rangle$ direction.

(3) $\beta^{\prime}$-sialon whiskers, with about $0.7 \mu \mathrm{m}$ diameter and $z=0.8$ to 1.1 , are synthesized by the present process. (4) The application of a halide bath enhances the generation of $\mathrm{SiO}$ gas by dissolving the silica into the bath.

(5) The rate of supply of $\mathrm{N}_{2}$ gas is a critical factor not only for determining the growth of $\mathrm{Si}_{3} \mathrm{~N}_{4}$ but also for the formation of $\mathrm{Si}_{2} \mathrm{~N}_{2} \mathrm{O}$.

(6) The presence of $\mathrm{Al}$ stabilizes the $\beta$-type structure by forming $\beta^{\prime}$-sialon and subsequently reducing $p_{\mathrm{O}_{2}}$ in the system.

\section{Acknowledgement}

This research is supported by NSF through MSM8719951 .

\section{References}

1. P. F. BECHER and G. C. WEI, J. Amer. Ceram. Soc. 67 (1984) C-267.

2. S. T. BULJAN, J. G. BALDONI and M. L. HUCKA BEE, Amer. Ceram. Soc. Bull. 66 (1987) 347.

3. D. F. HASSON, S. M. HOOVER and C. R. CROWE, J. Mater. Sci. 20 (1985) 4147.

4. S, V. NAIR, T. K. TIEN and R. C. BATES, Int. Met. Rev. 30 (1985) 275.

5. G. A. BOOTSMA, W. F. KNIPPENBERG and G. VERSPUI, J. Cryst. Growth 11 (1971) 297.

6. J. V. MILEWSKI, F. D. GAC, J. J. PETROVIC and S. R. SKAGGS, J. Mater. Sci. 20 (I985) 1160.

7. M. MATSUBARA, Y. NISHIDA, M. YAMADA, I. SHIRAYANAGI and T. IMAI, J. Mater. Sci. Lett. 6 (1987) 1313.

8. V. N. GRIBKOV, V. A. SILAEV, B. V. SCHETANOV, E. L. UMANTSEV and A. S. ISAIKIN, Soviet PhysicsCrystallography 16 (1972) 852.

9. T. HAYASHI, S. KAWABE and H. SAITO, Yogyokyokai-shi 94 (1986) 19.

10. H. WADA, M-J. WANG and T. Y. TIEN, J. Amer. Ceram. Soc. 71 (1988) 837

11. H. WADA and M-J. WANG, in Proceedings of International Conference on Whisker- and Fibre-Toughened Ceramics, Oak Ridge, USA, June 1988, edited by R. A. Bradley et al. (ASM International, 1988) p. 63.

12. K. H. JACK, J. Mater. Sci. 11 (1976) 1135.

13. H. HOHNKE and T. Y. TIEN, in "Progress in Nitrogen Ceramics", edited by F. L. Riely (Martinus Nijhoff Publishers, 1983) p. 101.

14. A. SZWEDA, A. HENDRY and K. H. JACK, in "Special Ceramics", Vol. 7, edited by J. Taylor and P. Popper (British Ceramics Society, Stoke-on Trent, 1981) p. 107.

15. T. MURAYAMA and H. WADA, in Proceedings of the 2nd International Symposium on Metallurgical Slags and Fluxes, Lake Tahoe, USA, November 1984, edited by H. A. Fine and D. R. Gaskell (Metall. Soc. AIME, 1984) p. 135. 
16. "Phase Diagrams for Ceramics", Vol. I (The American Ceramic Society, Inc.) p. 475.

17. H. SAITO, T. HAYASHI and K. MIURA, Nippon Kagaku Kaishi (1982) 401.

18. P. M. BILLS, J. Iron Steel Inst. 200 (1963) 133.

19. M. KATO and S. MINOWA, Trans. ISIJ 9 (1969) 31.

20. "Phase Diagrams for Ceramics", Vol. V (The American Ceramic Society, Inc.) p. 83
21. JANAF Thermochemical Tables, 3rd ed., (American Chemical Society and American Institute of Physics for National Bureau of Standards, 1986).

22. W. B. CAMPBELL, in "Whisker Technology", edited by A. P. Levitt (Wiley, New York, 1970) p. 37.

Received 1 November 1988 and accepted 12 April 1989 